\title{
Evaluation of antimicrobial sensitivity pattern of chronic suppurative otitis media in a tertiary care hospital of West Bengal, India
}

\author{
Shirsendu Mondal ${ }^{1 *}$, Manasi Banerjee ${ }^{1}$, Sudip Das ${ }^{2}$
}

\author{
${ }^{1}$ Department of Pharmacology, \\ Medical College, Kolkata, West \\ Bengal, India \\ ${ }^{2}$ Department of \\ Otorhinolaryngology, Bankura \\ Sammilani Medical College, \\ West Bengal, India \\ Received: 06 February 2017 \\ Accepted: 06 March 2017 \\ *Correspondence to: \\ Dr. Shirsendu Mondal, \\ Email: \\ mondalshirsendu@yahoo.com \\ Copyright: (c) the author(s), \\ publisher and licensee Medip \\ Academy. This is an open- \\ access article distributed under \\ the terms of the Creative \\ Commons Attribution Non- \\ Commercial License, which \\ permits unrestricted non- \\ commercial use, distribution, \\ and reproduction in any \\ medium, provided the original \\ work is properly cited.
}

\begin{abstract}
Background: Chronic suppurative otitis media is a common infectious disease in our country. The micro-organisms commonly causing the disease and their antibiotic sensitivity pattern is important for treatment. This study was conducted to evaluate the antimicrobial sensitivity pattern of the common microorganisms in patients with chronic suppurative otitis media in our tertiary care hospital.

Methods: The study was carried out from July 2013 to December 2013 at the ENT out-patient department of a tertiary care hospital in West Bengal. 100 patients aged 18 to 60 years of either sex, with unilateral or bilateral active chronic suppurative otitis media attending the out- patient clinic were included in the study. Pus samples were collected from the discharging ears and sent for isolating the organisms and susceptibility testing.

Results: A total number of 108 ear swabs were collected from the 100 recruited patients of which $15(13.88 \%)$ were sterile and $93(86.11 \%)$ showed presence of organisms. Pseudomonas aeruginosa 41(38\%) was the commonest organism isolated, followed by Staphylococcus aureus 25(23.15\%). The antimicrobial profile of the microorganisms reveals maximum sensitivity of the isolated organisms to piperacillin and levofloxacin.

Conclusions: In our study, Pseudomonas aeruginosa (38\%) and Staphylococcus aureus $(23.15 \%)$ are the major pathogens involved in the etiology of CSOM. The isolates showed maximum sensitivity to piperacillin $(41 \%)$ and levofloxacin $(41 \%)$. As piperacillin is available only in parenteral form and is also costly, topical levofloxacin can be recommended in empirical treatment of CSOM.
\end{abstract}

Keywords: Antimicrobial sensitivity pattern, Chronic suppurative otitis media, Pseudomonas aeruginosa

\section{INTRODUCTION}

Chronic Suppurative Otitis Media (CSOM) is defined as a chronic inflammation of the middle ear and mastoid cavity, which presents with recurrent ear discharges through a tympanic perforation. ${ }^{1}$ The classic term CSOM is no longer advocated as, chronic otitis media (COM) is not always associated with gathering of pus. Active COM is the condition of inflammation and production of pus. ${ }^{2}$ The disease usually begins in childhood as a spontaneous tympanic perforation due to an acute infection of the middle ear. Chronic otitis media could be a sequelae to active otitis media and otitis media with effusion. Depending on the involvement of the portion of the middle ear cleft, CSOM is of two types: tubotympanic (central perforation) and atticoantral or (marginal perforation). The disease has important long-term implications as there may be hearing impairment as well as language, auditory and cognitive impairment in children.

Patients suffering from CSOM are increasingly presenting in the ENT department of developing countries due to poor hygienic standards and poor nutrition. Studies show that both sexes and all age groups are affected by this disease. ${ }^{1,3,4}$ Global burden of illness from CSOM involves 65-330 million individuals with draining ears, $60 \%$ of whom suffer from significant 
hearing impairment. Over $90 \%$ of the burden is borne by countries in the South-east Asia and Western Pacific regions, Africa. ${ }^{1}$

Although bacterial culture is very essential in both types for specific choice of antibiotic, it is not always practically feasible in our setting. The commonly implicated organisms are aerobic bacteria (e.g. Pseudomonas aeruginosa, Escherichia coli, Staphylococcus aureus, Streptococcus pyogens, Proteus mirabilis, Klebsiella sp.) and anaerobic bacteria (e.g. Bacterioids, Peptostreptococcus, Propionibacterium). The organisms commonly causing the disease differs in various geographical areas. Widespread use of antibiotics has precipitated emergence of multiple resistant strains of bacteria, which leads to persistence of low-grade infections. Changes in the pattern of microbiological flora calls for reappraisal of their sensitivity to antibiotics, which can guide the clinician to plan a general outline of such treatment.

Studies have been done in different parts of the world and also in our country, regarding the bacteriologic profile of CSOM. $^{3-6}$ Data regarding the sensitivity profile of causative organisms of CSOM are sparse in the eastern region of our country. Thus we aim to evaluate the antibiotic sensitivity pattern of organisms causing CSOM in patients presenting at our hospital. As the treatment offered to patients is mostly empirical, knowledge about the recent trend in antibiotic sensitivity pattern of organisms commonly causing the disease in patients catering to our hospital would enable the physicians to be specific in the choice of antibiotics.

\section{METHODS}

This is a cross sectional observational study, done over a period of six months from July 2013 to December 2013. The study was approved by the Institutional Ethics Committee. Patients attending the ENT out-patient department of a tertiary care hospital in West Bengal were recruited for the study. One hundred patients aged 18 to 60 years of either sex, suffering from CSOM with unilateral or bilateral ear discharge were enrolled. Detailed clinical history was taken and clinical examination was done to identify the site of perforation. Patients having ear discharge of more than 2 months in duration were included in the study. Patients with inactive tubo-tympanic type of CSOM, CSOM with cholesteatoma, aural polyp or granulation, inflammatory external ear diseases, malignancy of the ear, those with diabetes or immunosuppressive disease were excluded. Those having received topical/systemic antibiotic or steroids (topical/systemic) in the last 4 weeks were also excluded.

Sterile cotton buds were used to collect pus swabs through the tympanic membrane perforation with the help of otoscope. The swabs were placed in sterile glass vials and transported to microbiology laboratory for study of culture/sensitivity. They were cultured on Blood agar, Chocolate agar and MacConkey's agar for aerobic bacterial culture and in Robertson's cooked meat media (RCM)/Thioglycolate media for anaerobic culture. Aerobic bacterial cultures were incubated at $37^{\circ} \mathrm{C}$ for $24-$ 48 hours. Organisms were isolated and identified according to standard microbiological methods. ${ }^{6}$ Antibacterial sensitivity of aerobic bacteria was carried out using the Kirby Bauer Disc diffusion technique.

A subculture from RCM was cultured on Blood agar and Macconkey's agar and the plates were put in a Macintosh Fildes jar with gaspack for anaerobic incubation. Fungal culture was performed on Sabouraud's dextrose agar.

\section{Statistical analysis}

Data was analysed using standard descriptive statistics with Graph pad instat 3.1 software.

\section{RESULTS}

A total number of 108 ear swabs were collected from the 100 recruited patients. The swabs were sent to the institutional laboratory for isolation of the causative organism and to evaluate the microbial sensitivity pattern to antibiotics.

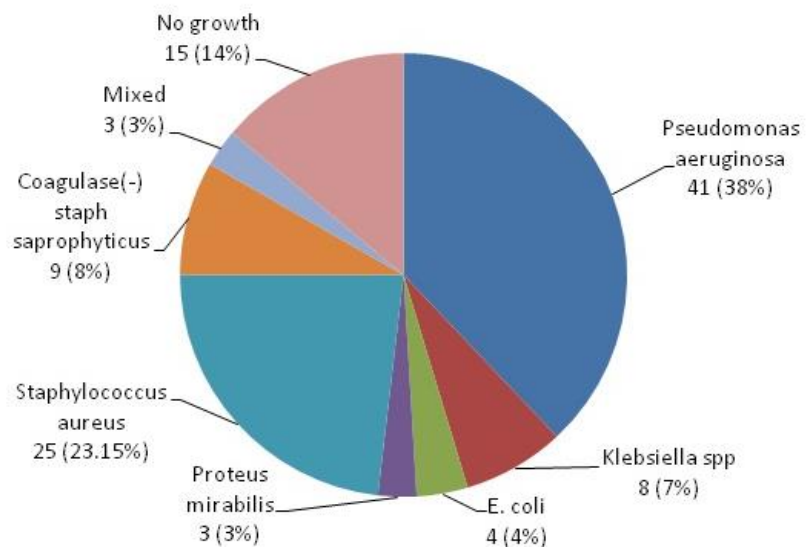

Figure 1: Microbiological profile of ear swabs.

Figure 1 shows the microbiological profile of the ear swabs. Out of the 108 swabs, 15 (13.88\%) were sterile and $93(86.11 \%)$ showed presence of organisms. Among the total number of isolates, majority were gram negative $(51.83 \%)$ as compared to Gram positive organisms (31.48\%). Pseudomonas aeruginosa was the commonest organism isolated in the gram-negative group followed by Klebsiella sp., Staphylococcus aureus was the commonest causative organism in the Gram positive group. Coagulase (-) staph saprophyticus is another important causative organism. Figure 2 shows the antimicrobial sensitivity pattern of the isolated organisms. The antimicrobial profile of the microorganisms reveals maximum sensitivity of the isolated organisms to piperacillin and levofloxacin (Figure 2). 
Table 1: Demographic profile of patients.

\begin{tabular}{|c|c|}
\hline Mean age of patients & 26.77 \\
\hline Male: Female & $51: 49$ \\
\hline Socio economic status Low: middle & $63: 37$ \\
\hline
\end{tabular}

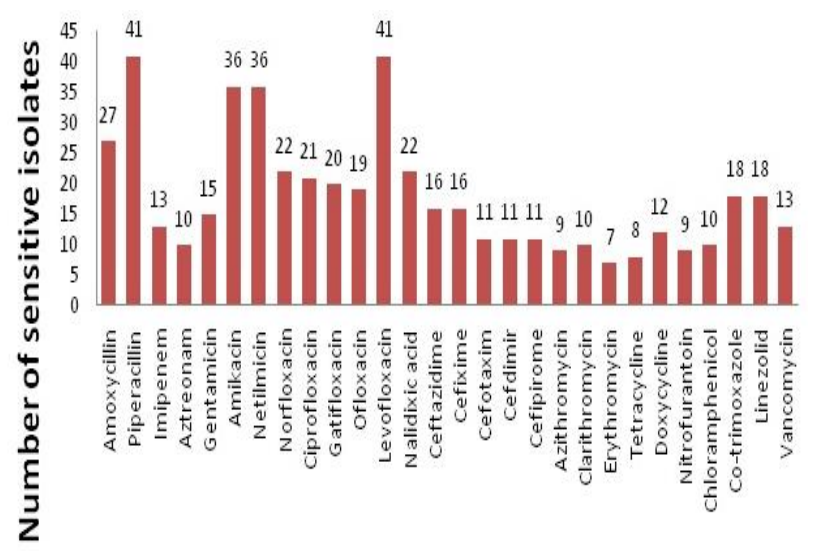

Figure 2: Antimicrobial sensitivity pattern of the isolated organisms.

Amikacin and netilmicin are the aminoglycoside antibiotics also shown to be effective against the causative microbes. The cephalosporins are not effectively sensitive against the isolates.

Table 2: Clinical profile of patients.

\begin{tabular}{|c|c|c|c|}
\hline Affected ear & $\begin{array}{l}\text { Right } \\
52\end{array}$ & $\begin{array}{l}\text { Left } \\
40\end{array}$ & $\begin{array}{l}\text { Both } \\
8\end{array}$ \\
\hline $\begin{array}{l}\text { Nature of } \\
\text { discharge }\end{array}$ & $\begin{array}{l}\text { Purulent } \\
22\end{array}$ & $\begin{array}{l}\text { Mucoid } \\
78\end{array}$ & \\
\hline $\begin{array}{l}\text { Amount of } \\
\text { discharge }\end{array}$ & $\begin{array}{l}\text { Profuse } \\
72\end{array}$ & $\begin{array}{l}\text { Scanty } \\
28\end{array}$ & \\
\hline Odour & $\begin{array}{l}\text { Foul } \\
27\end{array}$ & $\begin{array}{l}\text { Non-foul } \\
73\end{array}$ & \\
\hline Ear ache & $\begin{array}{l}\text { Yes } \\
57\end{array}$ & $\begin{array}{l}\text { No } \\
43\end{array}$ & \\
\hline Itching & $\begin{array}{l}\text { Yes } \\
50\end{array}$ & $\begin{array}{l}\text { No } \\
50\end{array}$ & \\
\hline Tinnitus & $\begin{array}{l}\text { Yes } \\
46\end{array}$ & $\begin{array}{l}\text { No } \\
54\end{array}$ & \\
\hline $\begin{array}{l}\text { Fullness in } \\
\text { ear }\end{array}$ & $\begin{array}{l}\text { Yes } \\
35\end{array}$ & $\begin{array}{l}\text { No } \\
65\end{array}$ & \\
\hline $\begin{array}{l}\text { Type of } \\
\text { perforation }\end{array}$ & $\begin{array}{l}\text { Central } \\
74\end{array}$ & $\begin{array}{l}\text { Marginal } \\
25\end{array}$ & $\begin{array}{l}\text { Attic } \\
1\end{array}$ \\
\hline $\begin{array}{l}\text { Grade of } \\
\text { deafness }\end{array}$ & $\begin{array}{l}\text { Mild } \\
12\end{array}$ & $\begin{array}{l}\text { Moderate } \\
74\end{array}$ & $\begin{array}{l}\text { Severe } \\
14\end{array}$ \\
\hline
\end{tabular}

\section{DISCUSSION}

Chronic suppurative otitis media is the result of an initial episode of acute otitis media, characterized by a persistent discharge from the middle ear through a tympanic perforation. Patients with tympanic perforations which continue to discharge mucoid material for periods of from 6 weeks to 3 months, despite medical treatment, are recognized as CSOM cases. It is an important cause of preventable hearing loss, particularly in the developing world.

The two principal aims of management are the eradication of infection and the closure of the tympanic perforation. Patients with CSOM who can be managed by conservative medical treatment usually experience mucoid, foul- or non-foul smelling oozing through a central tympanic perforation involving neither the drum margin nor its posterior region. For eradication of infection, the type of antimicrobial and the route of administration should be selected to suit the specific infecting organism. Daily instillation of topical antiseptics or topical antibiotics after meticulous aural toilet for at least 2 weeks appears to be the most costeffective treatment for the short-term resolution of otorrhoea. ${ }^{1}$

Studies in different countries have been done on the microbiological profile in CSOM. A study at Nepal isolated Staphylococcus aureus as the most common organism followed by Pseudomonas aeruginosa. ${ }^{7}$ Similar findings were concluded in a study done at Dehradun, and maximum sensitivity was seen to cephalosporins and fluoroquinilones. ${ }^{8}$ A study in Bangladesh showed beta hemolytic Streptococcus, Staphylococcus aureus, Pseudomonas and Streptococcus pneumonia as the most common organisms in children.

In the adults Staphylococcus aureus was the main offender. ${ }^{9}$ A study in Korea shows methicillin-resistant Staphylococcus aureus (MRSA) as the most frequent isolate $(26.5 \%)$ followed by Pseudomonas aeuginosa. ${ }^{10}$ Similar findings were seen in a study done in Philippines, which concluded that, the most common bacterial pathogens in CSOM are Staphylococcus aureus and Pseudomonas aeruginosa. Aminoglycosides, macrolides and quinolones were seen to be effective against most of the isolates of Staphylococcus aureus in this study. ${ }^{11}$

Our study has shown that Pseudomonas aeruginosa (38\%) and Staphylococcus aureus $(23.15 \%)$ are the major pathogen involved in the etiology of CSOM, which is at par with some other studies. ${ }^{7-9,12}$ The isolates showed maximum sensitivity to piperacillin (41\%) and levofloxacin (41\%). Sensitivity to amikacin and netilmicin were seen in $36 \%$ of isolates. As piperacillin is available only in parenteral form and is also costly, topical levofloxacin can be recommended in empirical treatment of CSOM.

\section{CONCLUSION}

In summary, CSOM is one of the most prevalent and preventable cause of childhood deafness and early empiric therapy is a need of the hour as the social impact of the disease is huge. But there is no consensus among the physicians regarding the choice of antibiotics because 
population or region based antibiotic sensitivity data is lacking. So, this is a humble attempt to look into this pertinent issue. Our study corroborated well with the other studies done in India and abroad in terms of clinicodemographic profile, microbiological profile and antibiotic sensitivity pattern. Levofloxacin emerged as the most sensitive topical preparation to be followed by Netilmicin. So, this study would provide a rational basis for selecting empirical drugs in CSOM in eastern India in set ups where micobiological logistics seems to be limited and it would also encourage many such attempts from different parts of India and elsewhere so as to formulate local guidelines in years to come.

Funding: No funding sources Conflict of interest: None declared

Ethical approval: The study was approved by the Institutional Ethics Committee

\section{REFERENCES}

1. Chronic suppurative otitis media. Burden of Illness and Management Options. Child and Adolescent Health and Development, Prevention of Blindness and Deafness. World Health Organization, Geneva, Switzerland. 2004:7-9.

2. Browning GG. Chronic otitis media. In: Gleeson M, Browning GG, Burton MJ, Clarke R, Hibbert J, Jones NS, editors. Scott-Brown's Otorhinolaryngology Head and Neck Surgery. 7th ed, London: Edward Arnold publishers. 2008;3:3396.

3. Loy AH, Tan AL, Lu PK. Microbiology of Chronic Suppurative Otitis Media in Singapur. Singapur Med J. 2002;43(6):296-9.

4. Nikakhlagh S, Khosarvi AD, Fazlipour A, Safarzadeh M, Rashidi N. Microbiologic findings in patients with chronic suppurative otitis media. J Med Sci. 2008;8:503-6.
5. Nazir A, Kadri SM. Aerobic bacteriology of chronic suppurative otitis media: a hospital based study. Int J Res Med Sci. 2014;2(4):1521-5.

6. Poorey VK, Iyer A. Study of bacterial flora in CSOM and its clinical significance. Indian $\mathrm{J}$ Otolaryngol Head and Neck Surg. 2002;54:91-2.

7. Srestha BL, Amatya RCM, Shestha I, Ghosh I. Microbiological profile of chronic suppurative otitis media. Nepalese J ENT Head Neck Surg. 2011;2(2):6-7.

8. Srivastava A, Singh RK, Varshney S, Gupta P, Bist SS, Bhagat $S$ et al. Microbiological Evaluation of an active tubotympanic type of chronic suppurative otitis media. Nepalese J ENT Head Neck Surg. 2010;1(2):14-6.

9. Haider A. Chronic suppurative otitis media (CSOM): bacteriological study. The ORION Med J. 2002;13:13-4.

10. Chang J, Lee SH, Choi J, Im GJ, Jung HH. Nasopharynx as a microbiologic reservoir in chronic suppurative otitis media: preliminary study. Clin Exp Otorhinolaryngol. 2011;4:122-5.

11. Ayson PN, Lopez JE, Llanes EG. Chronic suppurative otitis media: bacteriology and drug sensitivity patterns at the quirino memorial medical center (2004-2005): a preliminary study. Philipp J Otolaryngol Head Neck Surg. 2006;21:20-3.

12. Shyamala R, Reddy PS. The study of bacteriological agents of chronic suppurative otitis media - aerobic culture and evaluation. J. Microbiol Biotech Res. 2012,2(1):152-62.

Cite this article as: Mondal S, Banerjee M, Das S. Evaluation of antimicrobial sensitivity pattern of chronic suppurative otitis media in a tertiary care hospital of West Bengal, India. Int J Basic Clin Pharmacol 2017;6:891-4. 